\title{
Peningkatan Pemahaman Tata cara pernikahan Melalui Metode Role Playing dan Demonstrasi Pada Siswa Kelas XII
}

\author{
Amin Tantri Hidayah ${ }^{(1)}$ \\ ${ }^{1}$ SMA Negeri 1 Blitar, \\ Email: ${ }^{1}$ amintantrihidayah.@gmail.com
}

\begin{abstract}
ABSTRAK
Tujuan penelitian ini adalah meningkatkan pemahaman tata cara pernikahan melalui metode role playing dan demonstrasi pada siswa kelas XII IPA 6 SMA Negeri 1 Blitar. Penelitian ini merupakan Penelitian Tindakan Kelas (PTK) kolaboratif, yaitu bersifat praktis berdasarkan permasalahan riil dalam pembelajaran Pendidikan Agama Islam dengan materi ajar ijab qabul pada siswa Kelas XII IPA 6 SMA Negeri 1 Blitar. PTK merupakan penelitian yang bersiklus, yang terdiri dari rencana, aksi, observasi, dan refleksi yang dilakukan secara berulang. Berdasarkan hasil penelitian dan pembahasan dapat disimpulkan bahwa Pembelajaran melalui metode role playing dan demonstrasi dapat meningkatkan gairah siswa untuk berpartisipasi aktif dalam proses pembelajaran. Metode Pembelajaran role playing dan demonstrasi dapat meningkatkan pemahaman siswa terhadap mata pelajaran Pendidikan Agama Islam pada materi ajar Munakahat, sub materi tata cara pernikahan.
\end{abstract}

Kata kunci: tata cara pernikahan, role playing, demonstrasi,

\section{PENDAHULUAN}

Kegiatan belajar mengajar adalah suatu kegiatan yang bernilai edukatif. Nilai edukatif mewarnai interaksi yang terjadi antara guru dengan anak didik. Interaksi yang bernilai edukatif dikarenakan kegiatan belajar mengajar yang dilakukan, diarahkan untuk mencapai tujuan tertentu yang telah dirumuskan sebelum pengajaran dilakukan. Guru dengan sadar merencanakan kegiatan pengajaran secara sistematis dengan memanfaatkan segala sesuatunya guna kepentingan pengajaran.

Di SMA Negeri 1 Blitar, pemahaman siswa kelas XII IPA 6 pada materi ajar Munakahat, sub materi tata cara pernikahan sangat rendah dilihat hasil tes praktik pada semester 1 tahun pelajaran 2016/2017 dengan rata-rata nilai di bawah KKM. Hal ini disebabkan metode yang diterapkan guru tidak sesuai dengan tujuan.

Tatacara pernikahan merupakan salah satu materi yang diajarkan pada mata pelajaran pendidikan Agama Islam, khususnya di kelas XI. Kata nikah berasal dari bahasa arab yang berarti bertemu, berkumpul. Menurut istilah nikah ialah suatu ikatan lahir batin antara seorang laki-laki dan perempuan untuk hidup bersama dalam suatu rumah tangga melalui aqad yang dilakukan menurut hukum syariat Islam. Menurut UU No : 1 tahun 1974, Perkawinan ialah ikatan lahir batin antara seorang pria dan wanita sebagai suami istri dengan tujuan membentuk rumah tangga (keluarga) yang bahagia dan kekal berdasarkan Ketuhanan YME. Keinginan untuk menikah adalah fitrah manusia, yang berarti sifat pembawaan manusia sebagai makhluk Allah SWT.

Setiap manusia yang sudah dewasa dan sehat jasmani rokhaninya pasti membutuhkan teman hidup yang berlainan jenis, teman hidup yang dapat memenuhi kebutuhan biologis yang dapat dicintai dan mencintai, yang dapat mengasihi dan dikasihi, yang dapat diajak bekerja sama untuk mewujudkan ketentraman, kedamaian dan kesejahteraan hidup berumah tangga.

Untuk mengatasi permasalahan tersebut dilakukan suatu penelitian tindakan kelas dengan menerapkan metode role playing Demonstrasi. Metode role playing adalah cara penyajian pelajaran dengan meragakan atau mempertunjukkan kepada siswa suatu proses, situasi atau benda tertentu yang sedang dipelajari, baik 
sebenarnya ataupun tiruan yang sering disertai dengan penjelasan lisan (Djamarah \& Zain, 2006)

Metode role playing dan sosiodrama dapat dikatakan sama artinya, dan dalam pemakaiannya sering disilingantikan. Role playing atau sosiodrama pada dasarnya mendramatisasikan tingkah laku dalam hubungannya dengan masalah sosial.

Tujuan yang diharapkan dengan metode role playing antara lain (Djamarah \& Zain, 2006) Agar siswa dapat menghayati dan menghargai perasaan orang lain, Dapat belajar bagaimana membagi tanggung jawab, Dapat belajar bagaimana mengambil keputusan dalam situasi kelompok, Merangsang kelas untuk berpikir dan memecahkan masalah

Berikut ini adalah langkah-langkah pembelajaran dengan metode role play Guru menyusun/menyiapkan skenario yang akan ditampilkan, Menunjuk beberapa siswa untuk mempelajari skenario dalam waktu beberapa hari sebelum KBM, Guru membentuk kelompok siswa yang anggotanya 5 orang, Memberikan penjelasan tentang kompetensi yang ingin dicapai, Memanggil para siswa yang sudah ditunjuk untuk melakonkan skenario yang sudah dipersiapkan, Masing-masing siswa berada di kelompoknya sambil mengamaati skenario yang sedang diperagakan, Setelah selesai ditampilkan, masing-masing siswa diberikan lembar kerja untuk membahas penampilan masing-masing kelompok, Masing-masing kelompok menyampaikan hasil kesimpulannya, Guru memberikan kesimpulan secara umum, Evaluasi, Penutup.

Dari uraian di atas dapat disimpulkan bahawa pembelajaran dengan menggunakan metode role playing mempunyai keuntungan Siswa melatih dirinya untuk melatih, memahami, dan mengingat isi bahan yang akan didramakan. Sebagai pemain harus memahami, menghayati isi cerita secara keseluruhan, terutama untuk materi yang harus diperankannya. Dengan demikian, daya ingat siswa tajam dan tahan lama. Siswa akan terlatih berinisiatif dan berkreatif. Pada waktu bermain drama, para pemain dituntut untuk mengemukakan pendapatnya sesuai dengan waktu yang tersedia. Kerjasama antar pemain atau pemeran dapat ditumbuhkan dan dibina dengan sebaik-baiknya. Siswa memperoleh kebiasaan untuk menerima dan membagi tanggung jawab dengan sesamanya. Memupuk dan mengembangkan bakat atau potensi siswa.

Sedangkan Metode demonstrasi adalah adalah cara penyajian pelajaran dengan meragakan atau mempertunjukkan kepada siswa suatu proses, situasi, atau benda tertentu yang sedang dipelajari, baik sebenarnya ataupun tiruan yang sering disertai dengan penjelasan lisan (Djamarah \& Zain, 2006).

Dengan metode demonstrasi, proses penerimaan siswa terhadap pelajaran akan lebih berkesan secara mendalam sehingga membentuk pengertian dengan baik dan sempurna. Juga siswa dapat mengamati dan memperhatikan selama pelajaran berlangsung.

Dengan demikian maka metode demonstrasi baik digunakan untuk mendapatkan gambaran yang lebih jelas tentang hal-hal yang berhubungan dengan proses mengatur sesuatu, proses membuat sesuatu, proes bekerjanya sesuatu, proses mengerjakan atau menggunakannya, komponen-komponen yang membentuk sesuatu, membandingkan sesuatu cara dengan cara lain, dan untuk mengetahui atau melihat kebenaran sesuatu.

Dari uraian di atas menunjukkan bahwa metode demonstrasi dalam proses pembelajaran banyak bermanfaat, antara lain Dapat membuat pengajaran menjadi lebih jelas dan lebih konkret, sehingga menghindari verbalisme (pemahaman secara kata-kata atau kalimat) Siswa lebih mudah memahami apa ynng dipelajari. Proses pengajaran lebih menarik. Siswa dirangsang untuk aktif mengamati, menyesuaikan antar teori dengan kenyataan, dan mencoba melakukannya sendiri.

Sehingga rumusan masalah dalam penelitian ini adalah Apakah dengan menggunakan metode role playing dan demonstrasi dapat meningkatkan pemahaman tata cara pernikahan pada siswa kelas XII IPA 6 SMA Negeri 1 Blitar? sedangkan 
tujuan adalah meningkatkan pemahaman tata cara pernikahan melalui metode role playing dan demonstrasi pada siswa kelas XII IPA 6 SMA Negeri 1 Blitar.

\section{METODE}

\section{Setting Lokasi dan Subyek Penelitian}

Setting atau lokasi penelitian ini adalah SMA Negeri 1 Blitar Subyek pelaku tindakan adalah seorang guru mata pelajaran Pendidikan Agama Islam kelas XII. Subyek penelitian adalah siswa Kelas XII IPA 6 SMA Negeri 1 Blitar dan dilaksanakan pada bulan 7 September - 7 November 2015. Materi ajar yang diajarkan adalah Munakahat, sub materi tata cara pernikahan. Pemilihan kelas ini dilakukan dengan pertimbangan bahwa hasil belajar siswanya masih perlu ditingkatkan. Selain itu pembelajaran dengan menggunakan metode role playing dan demonstrasi belum pernah dilaksanakan di sekolah tersebut.

\section{Jenis Penelitian}

Penelitian ini merupakan Penelitian Tindakan Kelas (PTK) kolaboratif, yaitu bersifat praktis berdasarkan permasalahan riil dalam pembelajaran Pendidikan Agama Islam dengan materi ajar ijab qabul pada siswa Kelas XII IPA 6 SMA Negeri 1 Blitar. PTK merupakan penelitian yang bersiklus, yang terdiri dari rencana, aksi, observasi, dan refleksi yang dilakukan secara berulang.

Prosedur penelitian tindakan ini terdiri atas 2 siklus, dan kedua siklus tersebut merupakan rangkaian kegiatan yang saling berkaitan, artinya pelaksanaan siklus II merupakan kelanjutan dan perbaikan dari pelaksanaan siklus $\mathrm{I}$.

\section{Siklus \\ Rencana tindakan}

Setelah peneliti melaksanakan observasi awal, selanjutnya dilakukan perencanaan tindakan, observasi, dan refleksi. Menyusun rancangan pembelajaran dengan membuat silabus dan Rencana Pelaksanaan Pembelajaran (RPP). Menyusun instrumen pembelajaran yang meliputi pembuatan format pengamatan atau lembar observasi terhadap pelaksanaan tindakan yang terdiri atas lembar instrumen kinerja guru dan instrumen kinerja siswa.

\section{Pelaksanaan tindakan}

Pada pelaksanaan tindakan yang akan dilakukan peneliti adalah dengan menerapkan pembelajaran melalui metode role playing dan demonstrasi.. Proses pembelajaran disesuaikan dengan RPP yang telah dibuat. Proses pembelajaran tidak berlangsung satu arah tetapi ada interaksi antara guru sebagai peneliti dan siswa.

Guru memberi penjelasan secara klasikal tentang hal-hal yang akan dilakukan siswa selama proses pembelajaran berlangsung. Pada pembelajaran kelompok, guru membentuk kelompok, kelompok mendemonstrasikan peran masing-masing dan dilakukan pengamatan dan penilaian oleh kelompok lain.

\section{Observasi}

Observasi dilaksanakan oleh observer dan guru dengan mencatat kejadiankejadian yang ditimbulkan dalam pembelajaran baik positip maupun negatif., terutama pada pemahan siswa terhadap materi ajar, apakah mengalami perkembangan atau tetap, atau bahkan menurun.

\section{Refleksi}

Pada akhir siklus diadakan refleksi terhadap hasil pembelajaran yang diperoleh, baik dari hasil tes lisan, catatan guru, dan pengamatan. Dari hasil pengamatan observer selama proses pembelajaran berlangsung, ditemukan informasi tentang kelebihan dan kekurangan pada proses pembelajaran siklus I. Data yang diperoleh akan didiskusikan dengan wali kelas, guru mata pelajaran Pendidikan Agama Islam, dan rekan guru selaku observer. Hasil dari refleksi ini akan dijadikan pijakan 
atau sebagai bahan perbaikan pada siklus II yang pelaksanaannya sama dengan siklus I dengan memperhatikan segala kelemahan dan kelebihan pada siklus

\section{Instrumen Penelitian}

Instrumen penelitian yang digunakan dalam penelitian ini adalah lembar observasi kinerja siswa dan lembar observasi kinerja guru. Lembar observasi kinerja siswa digunakan untuk mengukur tingkat pemahaman siswa terhadap materi ajar, sedang lembar observasi kinerja guru digunakan untuk mengukur tingkat kemampuan guru dalam menerapkan metode pembelajaran di kelas selama proses pembelajaran berlangsung.

\section{Teknik pengumpulan data}

Sumber data dalam penelitian ini dapat diperoleh dari siswa, guru mata pelajaran Pendidikan Agama Islam, rekan guru dan peneliti sendiri. Data yang diambil dalam penelitian ini adalah data pemahaman siswa terhadap materi ajar dengan memberikan tes perbuatan atau praktek dan data hasil belajar psikomotorik siswa yang diperoleh dengan tes perbuatan atau praktek.

\section{Analisis Data}

Data hasil observasi pemahaman siswa terhadap mata pelajaran Pendidikan Agama Islam dengan materi ajar Munakahat, sub materi tata cara pernikahan dapat diidentifikasi pada saat tes perbuatan atau praktek. Persentase ketercapaian tindakan siswa dihitung dengan rumus.

\section{Persentase Keberhasilan Siswa $=$}

$$
\begin{gathered}
\text { Jumlah skor yang } \\
\text { dicapai }
\end{gathered}
$$$$
\text { X } 100 \%
$$

Jumlah skor maksimum

Data hasil observasi kegiatan guru dalam proses pembelajaran melalui metode role playing dan demonstrasi dianalisis secara deskriptif berdasarkan ketercapaian tindakan guru (peneliti) yaitu pencapaian langkah-langkah pembelajaran yang dilakukan oleh guru. Persentase ketercapaian tindakan guru dihitung dengan rumus.

$$
\text { Persentase skor keberhasilan }=\quad \begin{gathered}
\text { Jumlah skor yang dicapai } \\
\text { Jumlah skor maksimum }
\end{gathered} \quad \text { X 100\% }
$$

\begin{tabular}{|c|c|c|c|c|c|c|c|c|c|c|c|c|}
\hline \multicolumn{7}{|c|}{ Siklus I } & \multicolumn{6}{|c|}{ Siklus II } \\
\hline \multirow{2}{*}{ Subyek } & \multicolumn{4}{|c|}{ Aspek Psikomotor } & \multirow{2}{*}{ Jumlah } & \multirow{2}{*}{$\begin{array}{c}\text { Rerata/ } \\
\text { Nilai }\end{array}$} & \multicolumn{4}{|c|}{ Aspek Psikomotor } & \multirow{2}{*}{ Jumlah } & \multirow{2}{*}{$\begin{array}{c}\text { Rerata/ } \\
\text { Nilai }\end{array}$} \\
\hline & A & B & C & D & & & $\mathbf{A}$ & B & C & D & & \\
\hline 1 & 3 & 2 & 3 & 2 & 10 & 2.5 & 3 & 4 & 4 & 4 & 15 & 3.75 \\
\hline 2 & 3 & 3 & 3 & 2 & 11 & 2.75 & 4 & 4 & 4 & 3 & 15 & 3.75 \\
\hline 3 & 3 & 2 & 2 & 2 & 9 & 2.25 & 3 & 4 & 4 & 3 & 14 & 3.5 \\
\hline 4 & 2 & 2 & 3 & 3 & 10 & 2.5 & 4 & 4 & 3 & 3 & 14 & 3.5 \\
\hline 5 & 2 & 2 & 2 & 3 & 9 & 2.25 & 3 & 3 & 3 & 3 & 12 & 3 \\
\hline 6 & 1 & 2 & 2 & 1 & 6 & 1.5 & 3 & 3 & 2 & 3 & 11 & 2.75 \\
\hline 7 & 1 & 2 & 1 & 2 & 6 & 1.5 & 1 & 3 & 3 & 4 & 11 & 2.75 \\
\hline
\end{tabular}

HASIL demonstrasi.

Hasil pemahaman siswa terhadap materi ajar melalui metode role playing dan

Tabel 1. Skor Hasil Pemahaman Siswa Tentang Tata cara pernikahan 
Vol. 1 No. 1, Oktober 2017

\begin{tabular}{|c|c|c|c|c|c|c|c|c|c|c|c|c|}
\hline 8 & 2 & 1 & 2 & 1 & 6 & 1.5 & 3 & 3 & 3 & 2 & 11 & 2.75 \\
\hline 9 & 2 & 2 & 1 & 1 & 6 & 1.5 & 2 & 4 & 3 & 3 & 12 & 3 \\
\hline 10 & 1 & 2 & 2 & 3 & 8 & 2 & 2 & 3 & 3 & 3 & 11 & 2.75 \\
\hline 11 & 1 & 2 & 2 & 2 & 7 & 1.75 & 3 & 2 & 3 & 4 & 12 & 3 \\
\hline 12 & 2 & 1 & 2 & 3 & 8 & 2 & 3 & 2 & 4 & 4 & 13 & 3.25 \\
\hline 13 & 2 & 2 & 3 & 3 & 10 & 2.5 & 2 & 3 & 4 & 3 & 12 & 3 \\
\hline 14 & 2 & 1 & 2 & 3 & 8 & 2 & 4 & 4 & 3 & 4 & 15 & 3.75 \\
\hline 15 & 2 & 1 & 3 & 3 & 9 & 2.25 & 2 & 4 & 4 & 4 & 14 & 3.5 \\
\hline 16 & 1 & 3 & 2 & 1 & 7 & 1.75 & 3 & 2 & 3 & 3 & 11 & 2.75 \\
\hline 17 & 2 & 2 & 3 & 3 & 10 & 2.5 & 4 & 3 & 4 & 3 & 14 & 3.5 \\
\hline 18 & 2 & 2 & 2 & 2 & 8 & 2 & 3 & 3 & 4 & 4 & 14 & 3.5 \\
\hline 19 & 1 & 1 & 2 & 2 & 6 & 1.5 & 3 & 2 & 4 & 3 & 12 & 3 \\
\hline 20 & 1 & 2 & 2 & 1 & 6 & 1.5 & 3 & 3 & 3 & 3 & 12 & 3 \\
\hline 21 & 1 & 1 & 2 & 1 & 5 & 1.25 & 2 & 4 & 3 & 2 & 11 & 2.75 \\
\hline 22 & 2 & 2 & 1 & 2 & 7 & 1.75 & 4 & 4 & 3 & 4 & 15 & 3.75 \\
\hline 23 & 2 & 1 & 2 & 2 & 7 & 1.75 & 4 & 3 & 3 & 4 & 14 & 3.5 \\
\hline 24 & 2 & 1 & 2 & 2 & 7 & 1.75 & 2 & 3 & 3 & 3 & 11 & 2.75 \\
\hline 25 & 1 & 2 & 2 & 1 & 6 & 1.5 & 3 & 3 & 4 & 3 & 13 & 3.25 \\
\hline 26 & 2 & 2 & 2 & 1 & 7 & 1.75 & 3 & 3 & 4 & 4 & 14 & 3.5 \\
\hline 27 & 1 & 1 & 2 & 2 & 6 & 1.5 & 3 & 3 & 3 & 2 & 11 & 2.75 \\
\hline 28 & 2 & 1 & 2 & 2 & 7 & 1.75 & 4 & 3 & 4 & 3 & 14 & 3.5 \\
\hline Jumlah & 49 & 48 & 59 & 56 & 212 & 53 & 83 & 89 & 95 & 91 & 358 & 89.5 \\
\hline Rerata & 1.8 & 1.7 & 2.1 & 2.0 & 7.6 & 1.9 & 3.0 & 3.2 & 3.4 & 3.3 & 12.8 & 3.2 \\
\hline Kategori & C & C & C & C & & C & B & B & B & B & & B \\
\hline
\end{tabular}

1. Aspek psikomotorik

2. Rerata/Nilai

$\begin{array}{ll}: A=\text { Bacaan, } B=\text { Fashahah, } C=\text { Sikap, } \\ : 4=\text { Sangat baik } & 2=\text { Cukup } \\ 3=\text { Baik } & 1=\text { Kurang }\end{array}$

Tabel 2 Taraf Keberhasilan Tindakan Ditinjau dari Aspek Siswa

\begin{tabular}{|c|c|c|c|c|c|}
\hline $\begin{array}{c}\text { Siklus } \\
\text { ke- }\end{array}$ & $\begin{array}{c}\text { Skor Klasikal } \\
\text { yang diperoleh }\end{array}$ & $\begin{array}{c}\text { Skor klasikal } \\
\text { maksimum }\end{array}$ & $\begin{array}{c}\text { Persentase } \\
\text { keberhasila } \\
\mathrm{n}\end{array}$ & $\begin{array}{c}\text { Nilai } \\
\text { (Angka) }\end{array}$ & $\begin{array}{c}\text { Nilai } \\
\text { (Huruf) }\end{array}$ \\
\hline 1 & 212 & 448 & $47 \%$ & 1,9 & Cukup \\
\hline 2 & 358 & 448 & $80 \%$ & 3,2 & Baik \\
\hline
\end{tabular}

Hasil kegiatan guru selama proses pembelajaran berlangsung melalui metode role playing dan demonstrasi.

Tabel 3 Skor aktvitas guru

\begin{tabular}{|c|c|c|c|c|c|c|c|c|c|c|c|}
\hline \multirow{3}{*}{ No } & \multirow{3}{*}{ Aspek yang diamati } & \multicolumn{5}{|c|}{ SIKLUS I } & \multicolumn{5}{|c|}{ SIKLUS II } \\
\hline & & \multicolumn{4}{|c|}{ Penilaian } & \multirow{2}{*}{ Skor } & \multicolumn{4}{|c|}{ Penilaian } & \multirow{2}{*}{ Skor } \\
\hline & & 1 & 2 & 3 & 4 & & 1 & 2 & 3 & 4 & \\
\hline & I. PENDAHULUAN & & & & & & & & & & \\
\hline 1 & Menyampaikan Tujuan & & & $\square$ & & 3 & & & & $\square$ & 4 \\
\hline 2 & Memotivasi siswa & & & $\square$ & & 3 & & & & $\square$ & 4 \\
\hline 3 & Mengaitkan & & & $\square$ & & 3 & & & $\square$ & & 3 \\
\hline
\end{tabular}


Vol. 1 No. 1, Oktober 2017

\begin{tabular}{|c|c|c|c|c|c|c|c|c|}
\hline & II. KEGIATAN INTI & & & & & & & \\
\hline 1 & $\begin{array}{l}\text { Secara klasikal menjelaskan } \\
\text { metode pembelajaran }\end{array}$ & & $\square$ & & 3 & & $\square$ & 4 \\
\hline 2 & $\begin{array}{l}\text { Menyampaikan kepada siswa } \\
\text { tentang metode yang akan } \\
\text { digunakan }\end{array}$ & $\square$ & & & 2 & $\square$ & & 3 \\
\hline 3 & $\begin{array}{l}\text { Menunjuk beberapa siswa untuk } \\
\text { mendemonstrasikan tata cara } \\
\text { pernikahan }\end{array}$ & & & & 0 & $\square$ & & 3 \\
\hline 4 & $\begin{array}{l}\text { Membentuk kelompok dan } \\
\text { menunjuk siswa untuk } \\
\text { memerankan peran masing- } \\
\text { masing }\end{array}$ & & $\square$ & & 3 & $\square$ & & 3 \\
\hline 5 & $\begin{array}{l}\text { Menyuruh siswa untuk } \\
\text { melaksanakan perannya } \\
\text { masing-masing }\end{array}$ & $\square$ & & & 2 & & $\square$ & 4 \\
\hline 6 & $\begin{array}{l}\text { Siswa mendemonstrasikan } \\
\text { peran masing- } \\
\text { masing sesuai petunjuk guru }\end{array}$ & $\square$ & & & 2 & & $\square$ & 4 \\
\hline 7 & $\begin{array}{l}\text { Mengamati, mengawasi, } \\
\text { meneliti, dari masing-masing } \\
\text { peran }\end{array}$ & $\square$ & & & 2 & $\square$ & & 2 \\
\hline 8 & $\begin{array}{l}\text { Memberi arahan kepada siswa } \\
\text { tentang peran masing-masing } \\
\text { peran }\end{array}$ & & $\square$ & & 3 & & $\square$ & 3 \\
\hline 9 & $\begin{array}{l}\text { Mendiskusikan hasil peran } \\
\text { masing-masing kelompok }\end{array}$ & & $\square$ & & 3 & $\square$ & & 3 \\
\hline 10 & $\begin{array}{l}\text { Mengevaluasi siswa tentang } \\
\text { masing- } \\
\text { masing peran siswa dari awal } \\
\text { sampai akhir }\end{array}$ & & $\square$ & & 3 & $\square$ & & 3 \\
\hline & & & & & & & & \\
\hline & III. PENUTUP & & & & & & & \\
\hline 1 & $\begin{array}{l}\text { Menyimpulkan materi bersama- } \\
\text { sama }\end{array}$ & & $\square$ & & 3 & $\square$ & & 3 \\
\hline 2 & $\begin{array}{l}\text { Memberikan tugas menghafal } \\
\text { lafadz dan bacaan ijab qabul }\end{array}$ & & & $\square$ & 4 & & $\square$ & 4 \\
\hline 3 & $\begin{array}{l}\text { Melakukan refleksi tentang } \\
\text { materi yang telah dipelajari }\end{array}$ & & & $\square$ & 4 & & $\square$ & 4 \\
\hline & IV. PENGELOLAAN WAKTU & & & $\square$ & 4 & & $\square$ & 4 \\
\hline & $\begin{array}{l}\text { V. PENGAMATAN SUASANA } \\
\text { KELAS }\end{array}$ & & & & & & & \\
\hline 1 & Guru antusias & & $\square$ & & 3 & & $\square$ & 4 \\
\hline 2 & Siswa antusias & $\square$ & & & 2 & & $\square$ & 4 \\
\hline & Jumlah & & & & 52 & & & 66 \\
\hline & Rerata / Nilai & & & & 2.7 & & & 3.5 \\
\hline
\end{tabular}


Tabel 4. Taraf Keberhasilan Tindakan Ditinjau dari Aspek Guru.

\begin{tabular}{|c|c|c|c|c|c|}
\hline $\begin{array}{c}\text { Siklus } \\
\text { ke- }\end{array}$ & $\begin{array}{c}\text { Skor Klasikal } \\
\text { yang diperoleh }\end{array}$ & $\begin{array}{c}\text { Skor klasikal } \\
\text { maksimum }\end{array}$ & $\begin{array}{c}\text { Persentase } \\
\text { keberhasila } \\
\mathrm{n}\end{array}$ & $\begin{array}{c}\text { Nilai } \\
\text { (Angka) }\end{array}$ & $\begin{array}{c}\text { Nilai } \\
\text { (Huruf) }\end{array}$ \\
\hline 1 & 52 & 76 & $68 \%$ & 2.7 & Baik \\
\hline 2 & 66 & 76 & $87 \%$ & 3.5 & Sangat baik \\
\hline
\end{tabular}

\section{PEMBAHASAN}

Hasil penelitian pada siklus I, aktivitas pembelajaran mencapai 68\%, sedangkan hasil belajar siswa dalam memahami materi ajar $47 \% \mathrm{Hal}$ ini jauh dari apa yang diharapkan, dimana siswa dikatakan tuntas bila hasil belajar mencapai minimal $76 \%$. Dengan demikian hasil belajar siswa dalam memahami materi ajar belum mencapai ketuntasan belajar.

Untuk meningkatkan proses pembelajaran pada siklus II peneliti dengan dibantu oleh pengamat melakukan refleksi terhadap temuan-temuan pada siklus I.

Beberapa temuan pada siklus I yang perlu mendapat perhatian adalah kondisi ruang kelas yang tidak sesuai dengan jumlah siswa, respon dan partsipasi siswa rendah, belum munculnya kegiatan tanya jawab pada saat pembelajaran berlangsung. Temuan-temuan tersebut direfleksi baik oleh pengamat maupun peneliti dengan mengadakan perbaikan langkah-langkah atau kegiatan proses belajar mengajar.

Pada siklus II terjadi peningkatan proses pembelajaran klasikal menjadi $80 \%$ karena siswa mulai ada keberanian untuk menjawab pertanyaan yang diajukan oleh guru dan siswa mulai fres sehingga susana pembelajaran lebih menyenangkan. Dan hasil belajar siswa juga semakin meningkat yaitu mencapai rerata $80 \%$..

\section{KESIMPULAN}

Berdasarkan hasil penelitian dan pembahasan dapat disimpulkan bahwa Pembelajaran melalui metode role playing dan demonstrasi dapat meningkatkan gairah siswa untuk berpartisipasi aktif dalam proses pembelajaran. Metode Pembelajaran role playing dan demonstrasi dapat meningkatkan pemahaman siswa terhadap mata pelajaran Pendidikan Agama Islam pada materi ajar Munakahat, sub materi tata cara pernikahan.

\section{SARAN}

Dalam melaksanakan kegitan pembelajaran, guru hendaknya melakukan inovasi dan menggunakan metode pembelajaran yang bervariasi. Hal ini untuk mengatasi permasalahan pembelajaran yang cenderung kurang inovatif dan membosankan siswa.

\section{DAFTAR RUJUKAN}

Arikunto, S. 2001. Dasar-Dasar Evaluasi Pendidikan. Jakarta: Penerbit Bumi Aksara Djamarah, SB. 2006. Perencanaan Pengajaran Berdasarkan Pendekatan Sistem. Jakarta: PT Bumi Aksara.

Nasution, S. 1988. Metode Penelitian Naturalistik Kualitatif. Bandung: Penerbit Tarsito Nurhadi, \& Senduk, G., A., 2003. Pembelajaran Kontekstual dan Penerapannya dalam $K B K$. Malang: Universitas Negeri Malang.

Roestiyah. 2001. Strategi Pembelajaran, Menggagas Paradigma Baru Pendidikan. Jakarta : Radar Jaya Offset.

Sukmadinata, N.S. 2001. Pengembangan Kurikulum Teori dan Praktek. Bandung : PT Remaja Rosdakarya.

Surachmad, W. 1979. Metodologi Pengajaran Nasional. Jakarta

Syamsi, M. 2004. Kajian Fiqh. Jakarta: Lentera

Umar, Anshori. 1986. Fiqih Wanita. Semarang: CV. Asy-Syifa' 
JURNAL PENDIDIKAN: Riset \& Konseptual

Vol. 1 No. 1, Oktober 2017

Usman, U. M. 2002. Menjadi Guru Profesional. Edisi Kedua. Bandung: PT Remaja Rosdakarya.

Zuriah, N. 2003. Penelitian Tindakan dalam Bidang Pendidikan dan Sosial. Edisi Pertama. Malang: Bayu Media Publishing. 